\title{
X 線造影撮影法によるコンクリート性状調査
}

\author{
武田三弘
}

\section{1.はじめに}

既設コンクリート構造物の強度の推定には, 主に反発 硬度法やコア抜きによって行われることが多い。コンク リートの劣化診断を行う場合には, 表層から内部に向かっ てどのような量的变化をしながらどこまで劣化が進行し ているかを知ることが重要である。そこで，X 線造影 撮影法を用いて, 既設コンクリート構造物の表層部から 内部のひび割れ・空隙分布を調べることにより，コンク リートの性状調查老行った。対象としたコンクリート構 造物は，道路用縁石およびケーソンである。なお，この 調査は, 東北学院大学の大塚浩司教授之共同で行った調 査結果である。

\section{2. 対象構造物之調查方法}

\section{1 対象構造物}

対象とした構造物は，表層部が涷結融解作用により劣 化した材龄約 30 年の道路用縁石 (福島県郡山市内), 海 水中に埋没していた材齢 91 年のケーソン（東京湾）で ある。調査にあたり, 平成 16 年 2 月頃, 試料の採取 $(\phi 50,150 \mathrm{~mm})$ が行われた。

\section{2 X線造影撮影法}

コンクリートが施工上の問題や経年の劣化作用によっ て、コンクリート自体に微細なひび割れや初期欠陥なよ゙ の空隙が存在する場合, その箇所に造影剤（X 線の透 過を妨げる効果を屯った液体）が浸透すれば，X 線撮 影を行うことによって, その苗所を X 線フィルムに可 視的に検出することができる。

$\mathrm{X}$ 線造影撮影によるコンクリートの性状評価方法は, この特性を活かし，コンクリート中の空隙量を测定する

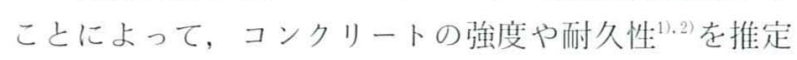
するものである。

具体的な万法としては, 図-1に示したように, 現場

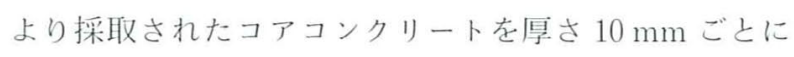
湿式ダイアモンドカッターでスライスし, 恒温恒湿室 (温度 $20^{\circ} \mathrm{C}$, 湿度 $60 \%$ ) に 24 時間放置してから, 本研 究室が開発した造影剤 (シシム系の $100 \mathrm{keV}$ で吸収 係数 $0.18 \mathrm{~cm}^{2} / \mathrm{g}$ ) で満たされた容器の中に試料を沈め, 压力を加えない状態でコンクリートに造影剤をしみ込ま せ, 60 分後に造影剂から取り出し, 表面に残った造影
剂をゴムワイパーで拭き取り，X 線撮影により, コン クリート内部に発生している微細ひび割れや初期欠陷な どの空隙量をX線フィルムに検出するものである。撮 影条件および撮影方法を表-1 および図-2に示す。なお， 造影剤浸透後の供試体について，他の調査に使用する場 合は，流水中に 1 週間ほど放置することによって，造影 剂を除去することができることが分かっている。

$\mathrm{X}$ 線撮影は, 造影剤を浸透させる前上, 浸透後 60 分

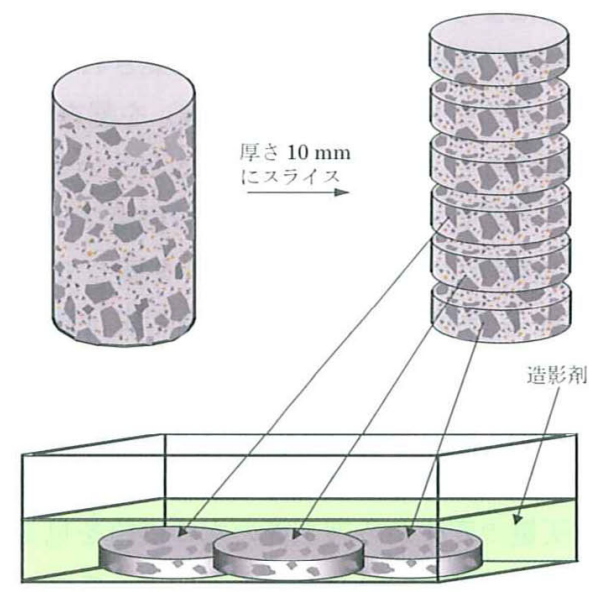

図-1＼cjkstart造影剂浸せき方法

表-1 撮影条件

\begin{tabular}{|c|c|c|}
\hline \multirow{5}{*}{$\begin{array}{c}\text { 据置型工場用 X 線発生装置 } \\
\text { WS-125 S }\end{array}$} & 管電压 & $100 \mathrm{kV}$ \\
\hline & 管電流 & $2 \mathrm{~mA}$ \\
\hline & 焦点・フィルム間距離 & $900 \mathrm{~mm}$ \\
\hline & 撮影時間 & $70 \mathrm{sec}$ \\
\hline & 焦点寸法 & $0.8 \times 0.8 \mathrm{~mm}$ \\
\hline フィルム & 工業用 X 線フィルム & $\mathrm{IX} \# 50$ \\
\hline 增感紙 & \multicolumn{2}{|c|}{ 鉙箔増感紙 $(0.03 \mathrm{~mm})$} \\
\hline
\end{tabular}

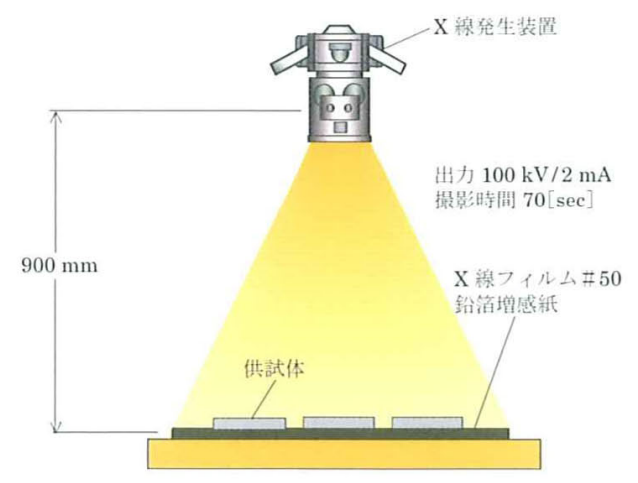

図-2 X 線造影撮影状況 
において撮影を行った。これは，両者のフィルムを比較 することによって, コンクリート内部に浸透した造影剤, つまり空隙量を測定するためである。撮影終了後, X 線フィルムは, 自動現像機（工業用 X-レイフィルムプ ロセッサーFIP-1000）を用いて現像を行った。

\section{3 微細ひび割れ・空隙の数值化方法}

$\mathrm{X}$ 線造影撮影法によって X 線フィルムに映し出され たコンクリート画像から, 微細ひび割れや初期欠陥など の等陌の数值化方法よして，両者のフィルム濃度差を用 いた。一般に，X線フィルムでは，X 線が透過した簓 所は黒くなり, 造影剤のような X 線を遮蔽する効果が 大きい物質がある筒所では, その遮蔽の程度によりフィ ルムは透明（本報告所内の画像では白）に近づく。した がって, 造影剤が多く浸透するような空陌が多いコンク リートに対してX線造影撮影した場合, 得られるフィ ルム画像の濃度自体は白くなる傾向となる。ここで, 造 影剤浸透前のフィルム濃度から造影剂浸透によって変化 したフィルム濃度を「透過線変化量」と定義し,この值 を用いてコンクリートの性状評価を行った。

透過線变化量の测定方法を図-3に示す。透過線变化 量の測定には照度計を用いた。照度とは「光があたって いる表面の単位面積当たりの光束の量」のことであり, その場所にどれだけの光が届いているかを測定するのが 照度計である。この照度計を用いることによって供試体 全体の平均的な $\mathrm{X}$ 線フィルム濃度老测定することが可 能となる。使用方法としては, シャウカステン（X 線 フィルム画像を観察する装置) の上に暗箱を置いた状態 で照度を測定し, その值を入射照度 $I_{0}$ とする。続いて, シャウカステン上に X 線フィルムを設置し, その上に 暗箱を置いた状態で照度を再度測定し，その時の照度を 透過照度 $I_{t}$ とする。これらの照度值を用いて, 式 (1) から X 線フィルム濃度を求める方法を使用した。

$$
D=\log \left(I_{o} / I_{t}\right)
$$

そして，造影剤に供試体を浸せきさせる前（以後，造 影剤浸透前とする）に撮影した X 線フィルム濃度 $D_{B}$ と各浸せき時間後（以後，造影剤浸透後上する）に撮影 した X 線フィルム濃度 $D_{A}$ とを求め, 式 (2) に示すよ うに，造影剤浸透前後のX線フィルムの濃度值を透過 線变化量 $T$ として, 微細ひび割れや初期欠陥などの空

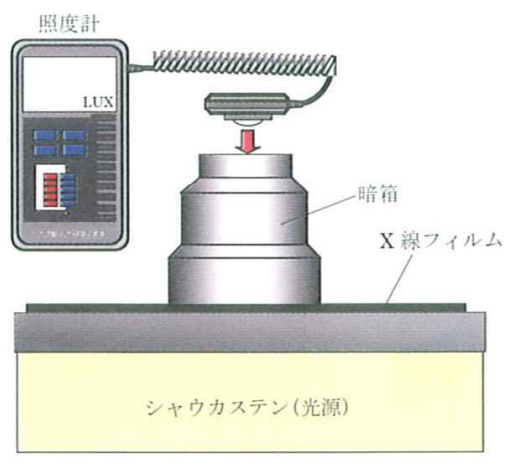

図-3 照度測定方法
隙量を表す指標とした。

$$
T=D_{B}-D_{A}
$$

なお，測定に使用した照度計のセンサーは，シリコン フォトダイオード（電気的性能 200〜2.0 105 Lux：分 解能 0.1 100）である。

3. 测定結果

\section{1 道路用縁石について}

写真-1 は, 30 年間道路に設置された縁石から採取さ れたコアコンクリート供試体を緣石上端部から厚さ 10 $\mathrm{mm}$ ごとに切断し，内部に発生した微細ひび割れや空 隙を, X 線造影撮影法により検出したものの一例（上 端より $60 \mathrm{~mm}$ の位置) である。写真の中で白く見える 簓所が，造影剤が浸透した箇所であり，骨材の周辺に多 く発生していることが分かる。

図-4は，X 線造影撮影により得られた透過線変化量 から求めた深さ方向の透過線变化量分布である。この図 より，供試体中心部の透過線变化量は小さく（空隙が少 なく)，上面上下面には多くのひび割れが発生している 結果となった。特に表層部である上面より，コンクリー 卜床版部之接している下面側に多くのひび割れが発生し ていることが分かった。これは，縁石作製時の作り方に よる影響と設置条件による影響とが考えられた。この縁 石は工場製品であり，作製時において，下面側よりコン クリートを流し込み作製されたため, 設置時における上 面部は下面部より密実なコンクリートであったと考えら

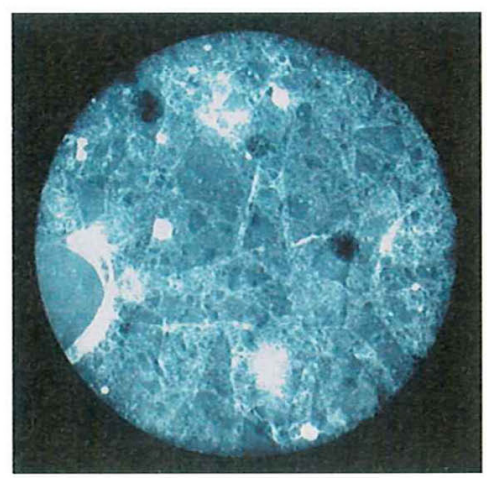

写真-1 X線フィルム（縁石）

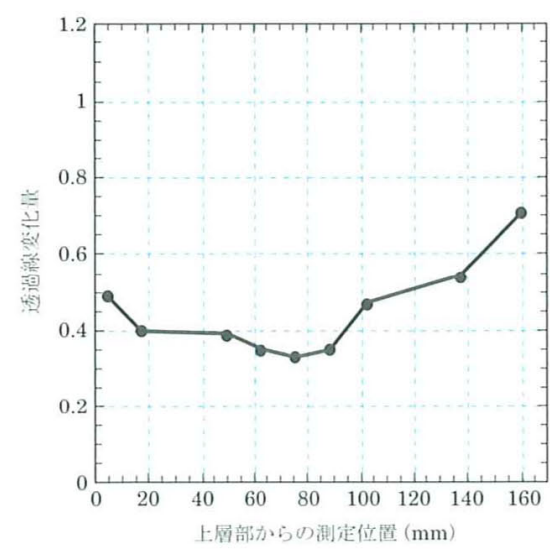

図-4 透過線变化量と供試体測定位置との関係 
れる。また, 下面部側は現場設置後，水が溜まりやすい 条件であることから，溶脱や凍結融解などの影響を受け やすかった屯のと考えられる。

\section{2 ケーソンについて}

写真-2 は, 材踰 91 年のケーソンよりコア抜きされた 供試体を表層から厚さ $10 \mathrm{~mm}$ ごとに切断し，内部に発 生した微細ひび割れや空隙を, X 線造影撮影法により 検出したものの一例である。このケーソンの表層部には モルタルが塗布されており, 内部は川砂利を使用したコ ンクリートである。この写真より, 表層部と内部を比較 した場合, 表層 (モルタル) 部には亀甲状のひび割れが 数多く検出されたが, 内部では骨材の周辺にひび割れが 一部見られるが欠陷部は少ないことが分かる。なお，表 層部の亀甲状のひび割れは, 目視では観察できなかった。

図-5は，表層から深さ万向に対して X 線造影撮影に より求めた, 透過線変化量と供試体測定位置（表層から

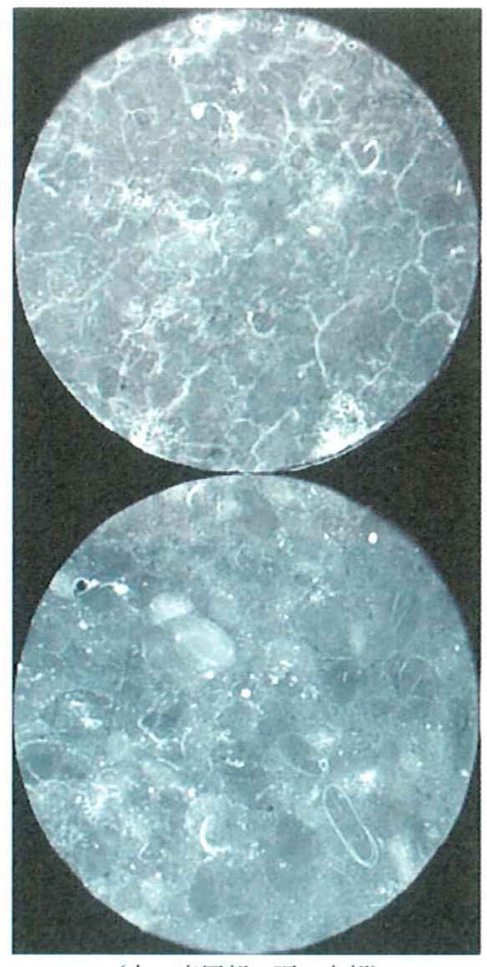

（上：表層部,下：内部）

写真-2 X線フィルム（ケーソン：申150 mm）

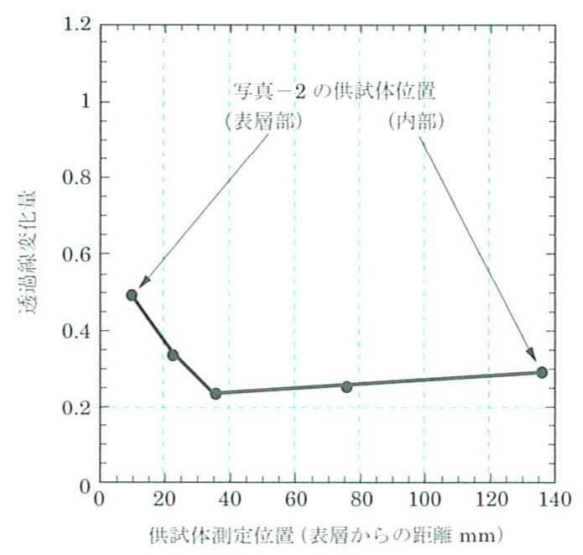

図-5 透過線変化量と供試体測定位置との関係
の距離）上の関係を求めたものである。この罒より, 表 層部の透過線变化量が一番大きく, 内部に進むに従って 小さくなり，約 $30 \mathrm{~mm}$ より深い位置ではほぼ一定にな る傾向がみられた。表層部には, モルタルが塗布されて いたため, $10 \mathrm{~mm}$ の位置では透過線変化量が大きい傾 向がみられたが, $23 \mathrm{~mm}$ の位置でも内部よりは透過線 変化量が大きいため, $30 \mathrm{~mm}$ の位置程度までは, 海水 による少化作用の影響があるものと考えら机る。表層よ り深さ $30 \mathrm{~mm}$ 以降を健全部と仮定した場合, この領域 の平均透過線変化量は 0.26 となり, 表層より約 $20 \mathrm{~mm}$ の位置の透過線变化量と比較した場合, 1.27倍, 表層 より約 $10 \mathrm{~mm}$ の位置では 1.88 倍の微細ひび割れが発 生していることがわかる。

\section{4. まとめ}

$\mathrm{X}$ 線造影撮影法を用いてコンクリートの表層から内 部にかけて発生している初期欠陥や微細なひび割れを検 出することによって，コンクリートの性状を評価してみ た。光の結果, いずれの場合む, ひび割れ発生状況を良 好に評価することが出来ることが分かった。現在，この 微細なひび割れの発牛量（透過線变化量）上強度や涷結 融解抵抗性との間には良好な相関関係がみられているこ とから,ひび割れの発生状況ばかりではなく、コンクリー トの強度や涷結融解抵抗性の評価屯可能になるものと考 えられる。

また, 今回の調査ではX X線フィルムによって得られ た画像から評価を行ったが, 現在, X 線透過画像を直 接コンピュータに取り込むことができる装置（イメージ インテンシファイアー）やその取り込まれた画像から, 直接, 透過線变化量の测定老行う画像処理装置を用いる ことによって，これまでよりさらに短時間で，高精度に コンクリートの性状評俩が可能になってきている。

\section{参考文献}

1）武田三弘・大塚浩司：X 線造影撮影によるコンクリート強度の推 定，土木学会論文集 E, Vol.62, No.2, pp.376 384, 2006.5

2）武田三弘・大塚浩司：X 線造影撮影によるコンクリート少化の数 值化之涷結融解抵抗性の判定, 上:不学会論文集 Vol.62, No.4, pp.728 738, 2006

3）特詐第 2113200 号；コンクリートのひひ割れ検出方法に用いる $\mathrm{X}$ 線造影剤及びコンクリートのひび割机検出方法, 1996

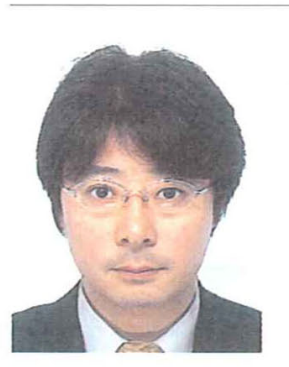

たけだ・みつひろ/東北学院大学 工学 部 環境建設工学科准教授（正会員） 